\title{
In vitro and In silico Antigout arthritic activities of Ethanolic and Aqueous stem extracts of Cissus quadrangularis - A TLR2 and TLR4 Receptor approach
}

\author{
Tharini Palani, Krishnan Shobha, Thirunavukkarasu P, Rajeswary Hari* \\ Department of Biotechnology Dr. M.G.R. Educational and Research Institute Deemed to be University, Chennai-95. Tamil Nadu, India.
}

\begin{tabular}{l}
\hline ARTICLE INFO \\
\hline Article history: \\
Received on: 05/07/2018 \\
Accepted on: 19/08/2018 \\
Available online: 30/09/2018
\end{tabular}

Key words:

Anti gout, Monosodium

urate, Toll-like receptor,

Xanthine oxidase.

\begin{tabular}{l}
\hline ABSTRACT \\
The in vitro anti-gouty arthritic activity of ethanolic and aqueous extracts of Cissus quadrangularis stem was evaluated \\
in terms of inhibition of xanthine oxidase, proteinase enzyme, protein denaturation and membrane stabilization. The \\
Monosodium Urate (MSU) up-regulated expression patterns of toll-like receptors namely TLR-2 and TLR-4 were \\
analyzed. The molecular docking was performed to select the antagonistic phyto ligand for receptors since their \\
activation leads to the destructive immunological reactions occurring in gouty arthritis. The in vitro anti-gout arthritic \\
activities were estimated using standard protocols. The MSU crystal-induced toll-like receptors gene expression was \\
analyzed. Molecular docking and LIGPLOT analysis were performed with the GCMS-derived phytoconstituents in \\
the ethanolic extract of Cissus quadrangularis with the receptors to find the interactions. Colchicine was used as a \\
positive drug in the study. Among the two extracts, ethanolic extract revealed better in-vitro anti-arthritic activity \\
in the present investigation. Out of the GCMS derived 13 phytocomponents, based on docking score three main \\
components namely Pentadecanoic acid, 14-methyl,-methyl ester, 10-Octadecenoic acid,methyl ester, 4-one,2-(3,4- \\
dihydroxyphenyl)-2,3-dihydro-3,5,7-trihydroxy showed better antagonistic action in the LIGPLOT analysis. It may be \\
concluded these three ligands may further develop as a potential anti-gouty arthritic drug.
\end{tabular}

MSU crystal by Toll-like receptor TLR2 and TLR4, which are normally involved in triggering the innate host defense responses to infectious pathogens, was recently discovered to be a primary trigger of the inflammatory and degenerative tissue reactions associated with gouty arthritis (Liu-Bryan et al., 2005; Liu-Bryan et al., 2005). Nonsteroidal anti-inflammatory drugs (NSAIDs), as well as systemic and intra-articular corticosteroids, are used to treat acute gout (Getting et al., 2002). In patients who cannot tolerate NSAIDs or systemic corticosteroids, oral colchicine is generally the next choice for primary therapy. But all these treatments have their own side effects such as gastrointestinal and liver toxicity.

It is a well-known fact that many Indian herbs are capable of a wide range of medicinal effects. From the time immemorial, mainly based on the practical experiences, these medicinal practices were developed and followed. Cissus quadrangularis is a medicinal plant which belongs to the Vitaceae family usually cultivated in India and Ceylon. In Ayurvedic system of medicine, this plant is used for the treatment of venereal diseases, gout, piles,
"Corresponding Author

Dr. Rajeswary Hari, Department of Biotechnology, Dr. M.G.R.

Educational \& Research Institute, Maduravoyal, Chennai, India.

E-mail: rajihar@gmail.com 
leucorrhoea and syphilis (Yoganarsimhan, 2006). Siddha traditional medicine believes the use of this plant to heal broken bones, as an analgesic and a tonic (Mishra et al., 2010). The pathophysiology of the gouty arthritis is characterized by multiple steps, where a potential drug should not only act to reduce the production of uric acid but should also reduce the immune response by inhibiting the activation of the Toll-like receptor and its downstream processes leading to the degenerative reactions involved in gouty arthritis. With the above scenario, the present investigation evaluated the and anti-gout activity of Cissus quadrangularis stem extracts through in vitro and insilico analysis.

\section{MATERIALS AND METHODS}

\section{Chemicals}

The chemicals used in the present study such as Ethanol, Bovine Serum Albumin, Acetyl Salicylic Acid were obtained from SD Fine Chemicals Ltd. Xanthine oxidase from bovine milk was purchased from Sigma $(\times 4500)$. Trypsin was purchased from SISCO Research Laboratories Pvt Ltd, Mumbai. The other chemicals used were of analytical grade.

\section{Collection of plant material}

The stem of Cissus quadrangularis was purchased from koyambdu market, Chennai, India and were authenticated by Dr.Sankaranarayanan, Deputy Director, captain Srinivasamorthy Siddha medical institute Chennai, India. The voucher specimen is also available in herbarium file of the same Centre.

\section{Preparation of plant extract}

The stem of Cissus quadrangularis (1 kg) was dried and ground into a coarse powder. The powder was extracted with $90 \%$ $(\mathrm{v} / \mathrm{v})$ ethanol at room temperature by cold maceration process for three days. The resultant extract was filtered and the excess solvent was removed by vacuum evaporator. The yield of the sample was calculated. Similarly, aqueous extract was prepared and the removal of water was carried out by freeze-drying and the yield of the sample is calculated. The prepared extracts were stored in the refrigerator until investigation.

\section{In vitro anti-arthritic activity of gouty arthritis}

The anti-arthritic activity of gouty arthritis was analyzed using standard established protocols. The in vitro Xanthine oxidase inhibitory activity, protein denaturation inhibition assay, membrane stabilization study, and Proteinase enzyme inhibition study were studied to assess the anti-arthritic activity of the plant extracts EECQ and AECQ. The activity of xanthine oxidase was calculated using spectrophotometer method by Owens and Johns 1999. The protein denaturation inhibition process was evaluated using Mizushima and Kobayashi, 1968 method. The membrane stabilization of RBC was carried out according to the studies by Sakat et al. (2010). The proteinase enzyme inhibitory studies were performed by the method of Oyedapo et al. (1995).

\section{Determination of totalphenolic content}

The total phenols present in the EECQ and AECQ extracts were calculated according to the methods of Slinkard and Singleton 1977. A quantity of $100 \mathrm{mg}$ of the sample in $0.5 \mathrm{ml}$ of water is mixed with Folin-Ciocalteu's reagent (diluted 1:10v/v) and $2 \mathrm{ml}$ of $\mathrm{Na}_{2} \mathrm{CO}_{3}(7.5 \%, \mathrm{v} / \mathrm{v})$ solution. The whole set up was incubated for $90 \mathrm{~min}$ at $30^{\circ} \mathrm{C}$, and the resultant color was measured at $765 \mathrm{~nm}$ with results expressed as gallic acid equivalents.

\section{Determination of total flavanoid content}

The total flavonoid content present in the extracts were calculated by the method of Zhishen et al. (1999). $100 \mathrm{mg}$ of test drugs were dissolved in $2 \mathrm{ml}$ of distilled water and $0.15 \mathrm{ml}$ of sodium nitrite solution. $0.15 \mathrm{ml}$ of aluminium chloride solution was added after 6 minutes and incubated for 6 minutes. To the mixture $2 \mathrm{ml}$ of $4 \%, \mathrm{NaOH}$ was added followed by the addition of water to bring the volume to $5 \mathrm{ml}$ and incubated for $15 \mathrm{~min}$, color absorbance was determined at $510 \mathrm{~nm}$ and results were expressed as catechin equivalents.

\section{GC-MS analysis}

For GC-MS analysis, the samples were injected into an HP-5 column $(30 \mathrm{~m} \times 0.25 \mathrm{~mm}$ i.d with $0.25 \mu \mathrm{m}$ film thickness $)$, Agilent technologies 6890 N JEOL GC Mate II GC-MS model. The following chromatographic conditions were used: Helium as a carrier gas, the flow rate of $1 \mathrm{~mL} / \mathrm{min}$; and the injector was operated at $200^{\circ} \mathrm{C}$ and column oven temperature was programmed as $50-250^{\circ} \mathrm{C}$ at a rate of $10^{\circ} \mathrm{C} / \mathrm{min}$ injection mode. The Following MS conditions were used: ionization voltage of $70 \mathrm{eV}$; ion source temperature of $250^{\circ} \mathrm{C}$; the interface temperature of $250^{\circ} \mathrm{C}$; mass range of 50-600 mass units.

\section{Monosodium urate crystals synthesis}

MSU crystals were prepared according to Seegmiller et al., $1962.24 \mathrm{~g}$ of sodium hydroxide was solubilized in $200 \mathrm{ml}$ of pyrogen-free double distilled water. $1 \mathrm{~g}$ of uric acid was added into the above solution and the $\mathrm{pH}$ was adjusted to 7.2 using $1 \mathrm{~N} \mathrm{HCl}$. This solution was heated to $120^{\circ} \mathrm{C}$ for 6-hrs with gentle stirring. After incubation, the solution was left to cool at room temperature and kept at $4^{\circ} \mathrm{C}$ for overnight. The sedimented MSU crystals were collected by filtration and washed with absolute ethanol. Washed MSU crystals were dried under vacuum and sterilized by autoclaving at $121^{\circ} \mathrm{C}$ for $20 \mathrm{~min}$. The sterilized crystals were prepared as $20 \mathrm{mg} / \mathrm{ml}$ stock in PBS and used for the assay.

\section{Cell treatment and quantitative Real-Time Polymerase Chain Reaction (RT-PCR) analysis of TLR4 and TLR2 expression}

A quantity of $1 \times 10^{6}$ cells/well of human PBMC were plated in $400 \mu \mathrm{l}$ volume on 24-well tissue culture plate and incubated for $30 \mathrm{~min}$ before compound treatment at $37^{\circ} \mathrm{C}$ under a humidified atmosphere of $95 \%$ air and $5 \% \mathrm{CO}_{2}$. Aliquotes of monosodium urate crystals were prepared in complete RPMI1640 medium and transferred to the respective wells the plates were gently rocked for few seconds. $100 \mu$ l of complete medium was added to the well served as untreated control. The plate was incubated at $37^{\circ} \mathrm{C}$ under a humidified atmosphere of $95 \%$ air and $5 \% \mathrm{CO}_{2}$ for $20 \mathrm{hrs}$. After incubation, the cells were collected by centrifugation at $3000 \mathrm{rpm}$ for $5 \mathrm{~min}$ at $4^{\circ} \mathrm{C}$. The supernatants were discarded and the cell pellets were washed with Phosphate buffered saline before RNA isolation processes. Total RNA was isolated from treated human PBMC cells using the TRIzol Reagent (Sigma) according to the manufacturer's instructions. The $2 \mu \mathrm{g}$ 
RNA was reverse transcribed by using the higher capacity cDNA reverse transcription kit (Applied Biosystems, CA, USA) and the mRNA expression was amplified by Quantitect SYBR1 PCR kit (QIAGEN, Valencia, CA, USA). Gene-specific primers for TLR4 and TLR2 expression were designed by referring to the NCBI/ primer-BLAST tool software which is depicted in the Table 1. The RT-PCR data was collected and analyzed on MxPro Software from Agilent Technologies. The fold change in gene expression levels of target genes was calculated with normalization to $\beta$-actin values using the 2- $\Delta \Delta \mathrm{Ct}$ comparative cycle threshold method.

\section{Molecular docking analysis}

In silico molecular docking studies were conducted with the help of patch dock to identify the best ligand for TLR2 and TLR4 proteins from the Cissus quandrangularis phyto compounds. The three-dimensional structures of toll-like receptor 4 (TLR-4) (PDB ID: 5NAO)and toll-like receptor 2 (TLR-2) (PDB ID:2Z80) proteins were downloaded from protein data bank (http://www.rcsb. org/pdb/). The two-dimensional structures for GC-MS identified 13 phyto constituents from the Cissus quandrangularis were retrieved from PUB chemsite, and converted into three-dimensional structures using corina $3 \mathrm{D}$ converter. Using the patch dock server docking score regarding the ligand and protein interaction was identified. Using ligand showing appropriate docking score was selected and their further interactions with the proteins in terms of amino acid residues with the ligand and the active site were visualized and further confirmed using LIGPLOT. The docked results were saved as "pdb" file and binding affinity and molecular interaction between standard, test compounds and the receptor protein were visualized using PyMol Molecular Graphic System (Ver. 1.0) and Discovery Studio (Ver. 3.1) software, respectively The standard drug colchicine is used as a reference drug.

\section{Statistical analysis}

The values reported are Mean \pm SE. The statistical analysis was carried out using analysis of variance (ANOVA) followed by Dunnet's ' $t$ ' test. The $p$ values $<0.05$ were considered significant.

\section{RESULTS}

\section{Xanthine oxidase inhibitory assay}

The Xanthine oxidase inhibitory activity of EECQ and AECQ were depicted in Table 2. Between these two extracts the ethanolic extract of Cissus quadrangularis shows higher the maximum inhibitory activity to xanthine oxidase starting from $50 \mu \mathrm{g}$ concentration when compared to aqueous extract of Cissus quadrangularis. In the present study, the percentage of inhibition was almost similar to allopurinol the positive drug used.

\section{Inhibition of protein denaturation}

The potential of inhibition of protein denaturation was studied (Table 3) and better inhibition was seen for EECQ than AECQ and at the concentration to $500 \mu \mathrm{g}$ and $1000 \mu \mathrm{g}$ of EECQ maximum inhibition potential was noted which was higher than the inhibition percentage of Acetylsalicylic acid the positive control used.

\section{Membrane stabilization study}

The heat and hypotonic saline-induced damage to RBC membrane was stabilized by the plant extracts (Table 4) and were comparable with the positive drug Acetylsalicylic acid. The EECQ extract protected the RBC membrane than the AECQ.

\section{Proteinase inhibition study}

The ability of the EECQ and AECQ to inhibit proteinase enzyme was shown in the Table 5. Though both the extracts showed proteinase inhibitory activity, the inhibition was found to higher for EECQ than AECQ extracts. In the present investigation the, $200 \mu \mathrm{g}$ to $1000 \mu \mathrm{g}$ of EECQ showed higher inhibitory activity than the Acetylsalicylic acid which was the positive drug used in this study.

Table 1: Details of Primers used for TLR-2, 4 and $\beta$-actin.

\begin{tabular}{cllc}
\hline Gene & Primer & Primer sequence & Size of the amplicon (BP) \\
\hline \multirow{2}{*}{ TLR-2 (NCBI Ref sequence NM_001318787.1) } & Forward & GGCCAGCAAATTACCTGTGT & 298 \\
& Reverse & TTCTCCACCCAGTAGGCATC & \\
TLR-4 (NCBI Ref sequence NM_138557.2) & Forward & TGAGCAGTCGTGCTGGTATC & 167 \\
& Reverse & CAGGGCTTTTCTGAGTCGT & 211 \\
$\beta$-actin (NCBI Ref sequence NM_001101) & Forward & CATCGAGCACGGCATCGTCA & \\
& Reverse & TAGCACAGCCTGGATAGCAAC & \\
\hline
\end{tabular}

Table 2: Effects of EECQ and AECQ on Inhibition of Xanthine Oxidase.

\begin{tabular}{cccc}
\hline Conc of Extract (in $\boldsymbol{\mu g}$ ) & \% Inhibition of EECQ & \% Inhibition of AECQ & \% Inhibition of Allopurinol \\
\hline 50 & $49.8 \pm 1.41 \mathrm{a}^{* *}$ & $34.26 \pm 0.9 \mathrm{~b}^{* *}$ & $70.3 \pm 0.7$ \\
100 & $56.8 \pm 1.4 \mathrm{a}^{* *}$ & $48.9 \pm 1.36 \mathrm{~b}^{* *}$ & $72.0 \pm 1.2$ \\
200 & $70.3 \pm 1.05 \mathrm{a}^{* *}$ & $56.2 \pm 0.75 \mathrm{~b}^{* *}$ & $75.2 \pm 0.76$ \\
500 & $83.5 \pm 2.6 \mathrm{a} \mathrm{ns}$ & $65.5 \pm 1.45 \mathrm{~b}^{* *}$ & $81.2 \pm 1.15$ \\
1000 & $91.53 \pm 1.35 \mathrm{a}^{* *}$ & $66.9 \pm 1.2 \mathrm{~b}^{* *}$ & $83.76 \pm 1.49$ \\
\hline
\end{tabular}

Values are expressed in mean $\pm \mathrm{SD}(\mathrm{n}=3)$, statistical significant test for comparison was done by ANOVA followed by Dunnet's ' $\mathrm{t}$ ' test. Comparison between a: Allopurinol vs. EECQ b: Allopurinol vs. AECQ *p $<0.05, * * p<0.1$ and ns: Non-Significant. 
Table 3: Effects of EECQ and AECQ on Inhibition of Protein Denaturation.

\begin{tabular}{|c|c|c|c|}
\hline Conc of Extract (in $\mu \mathrm{g}$ ) & \% Inhibition of EECQ & $\%$ Inhibition of AECQ & $\%$ Inhibition of Acetyl Salicylic Acid \\
\hline 50 & $49.8 \pm 1.41 \mathrm{a}^{* *}$ & $34.26 \pm 0.9 \mathrm{~b}^{* *}$ & $70.3 \pm 0.7$ \\
\hline 100 & $56.8 \pm 1.4 \mathrm{a}^{* *}$ & $48.9 \pm 1.36 \mathrm{~b}^{* *}$ & $72.0 \pm 1.2$ \\
\hline 200 & $70.3 \pm 1.05 \mathrm{a}^{* *}$ & $56.2 \pm 0.75 \mathrm{~b}^{* *}$ & $75.2 \pm 0.76$ \\
\hline 500 & $83.5 \pm 2.6$ a ns & $65.5 \pm 1.45 \mathrm{~b}^{* *}$ & $81.2 \pm 1.15$ \\
\hline 1000 & $91.53 \pm 1.35 \mathrm{a}^{* *}$ & $66.9 \pm 1.2 b^{* *}$ & $83.76 \pm 1.49$ \\
\hline
\end{tabular}

Values are expressed in mean $\pm S D(n=3)$, statistical significant test for comparison was done by ANOVA followed by Dunnet's ' $\mathrm{t}$ ' test. Comparison between a: Acetylsalicylic acid vs. EECQ b: Acetylsalicylic acid vs. AECQ *p $<0.05, * * p<0.1$ and ns: Non-Significant.

Table 4: Effects of EECQ and AECQ on membrane Stabilization.

\begin{tabular}{cccc}
\hline Conc of Extract (in $\boldsymbol{\mu g})$ & \% stabilization of EECQ & \% stabilization of AECQ & \% stabilization of Acetyl Salicylic Acid \\
\hline 50 & $50.2 \pm 0.95 \mathrm{a}^{* *}$ & $36.1 \pm 1.06 \mathrm{~b}^{* *}$ & $69.9 \pm 1.3$ \\
100 & $61.9 \pm 1.58 \mathrm{a}^{* *}$ & $51.2 \pm 1.10 \mathrm{~b}^{* *}$ & $74.2 \pm 0.95$ \\
200 & $71.5 \pm 1.25 \mathrm{a}^{* *}$ & $58.6 \pm 1.41 \mathrm{~b}^{* *}$ & $80.23 \pm 1.0$ \\
500 & $78.33 \pm 0.92 \mathrm{a}^{* *}$ & $63.9 \pm 1.45 \mathrm{~b}^{* *}$ & $82.8 \pm 1.22$ \\
1000 & $82.6 \pm 1.10 \mathrm{a} \mathrm{ns}$ & $67.8 \pm 2.4 \mathrm{~b}^{* *}$ & $83.8 \pm 1.5$ \\
\hline
\end{tabular}

Values are expressed in mean $\pm \mathrm{SD}(\mathrm{n}=3)$, statistical significant test for comparison was done by ANOVA followed by Dunnet's ' $\mathrm{t}$ ' test. Comparison between a: Acetylsalicylic acid vs. EECQ b: Acetylsalicylic acid vs. AECQ *p $<0.05, * * p<0.1$ and ns: Non-Significant.

Table 5: Effect of EECQ and AECQ on Proteinase Inhibition.

\begin{tabular}{cccc}
\hline Conc. of Extract (in $\boldsymbol{\mu g})$ & \% Inhibition of EECQ & \% Inhibition of AECQ & \% Inhibition of Acetyl salicylic acid \\
\hline 50 & $13.49 \pm 0.70 \mathrm{a}^{* *}$ & $10.57 \pm 0.84 \mathrm{~b}^{* *}$ & $23.27 \pm 0.67$ \\
100 & $26.56 \pm 0.60 \mathrm{aa} \mathrm{ns}$ & $20.44 \pm 0.75 \mathrm{~b}^{* *}$ & $27.40 \pm 1.29$ \\
200 & $40.20 \pm 1.19 \mathrm{a}^{*}$ & $35.72 \pm 0.79 \mathrm{~b} \mathrm{~ns}$ & $37.56 \pm 0.86$ \\
500 & $80.34 \pm 0.72 \mathrm{a} \mathrm{ns}$ & $72.52 \pm 0.75 \mathrm{~b}^{* *}$ & $79.56 \pm 0.86$ \\
1000 & $92.69 \pm 0.74 \mathrm{a}^{* *}$ & $86.31 \pm 0.78 \mathrm{~b}^{* *}$ & $89.28 \pm 0.68$ \\
\hline
\end{tabular}

Values are expressed in mean $\pm \mathrm{SD}(\mathrm{n}=3)$, statistical significant test for comparison was done by ANOVA followed by Dunnet's ' $\mathrm{t}$ ' test. Comparison between a: Acetylsalicylic acid vs. EECQ b: Acetylsalicylic acid vs. AECQ *p $<0.05, * * p<0.1$ and ns: Non-Significant.

\section{GCMS analysis}

In the present investigation, the ethanolic extract of Cissus quadrangularis revealed better anti arthritic activity than its aqueous extract. So the EECQ was subjected to GC-MS analysis which revealed the presence of 13 chemical components (Figure 1).

\section{MSU effect on TLR-2 and TLR-4 gene expression}

The effect of the MSU induced inflammatory response which is mediated by TLR-2 and TLR-4 receptors was studied using human peripheral blood mononuclear cells treated with monosodium urate crystals. The level of gene expression of these receptors with varying concentration of MSU crystals was studied using the RT-PCR method and depicted in Figure 2 and 3. In our present investigation, the expression pattern of TLR-2 was concentration-dependent that is at a lower concentration of MSU crystals such as $125 \mu \mathrm{g}$ the gene expression was minimum and then gradually increases with increase in concentration and peaks at $1000 \mu \mathrm{g}$. Whereas TLR-4 gene expression was independent on the concentration of MSU and at lower concentration $(125 \mu \mathrm{g})$ itself it showed maximum gene expression.

\section{Molecular docking analysis}

Molecular docking was performed for all the 13 compounds obtained from GCMS analysis with the TLR2 and TLR4 receptor using the patch dock sever and docking score was obtained (Table 6). Based on the docking score three compounds namely Pentadecanoic acid, 14-methyl,-methyl ester, 10-octadecenoic acid, methyl ester, 4-one, 2-(3,4-dihydroxyphenyl)-2,3-dihydro-3,5,7-trihydroxy- were selected for the study of ligand-protein interaction using the LIGPLOT analysis. The number and nature of aminoacid interaction through hydrogen bonding as well as hydrophobic interaction of the phyto compounds as well as the standard drug colchicine was explained in Table 7, Figure 3 and 4. From the previous studies it is noted that all these three compounds have the ability to bind with the amino acid arginine which was present in the active site of both TLR2 and TLR4 receptor by hydrogen bonding and thereby acting as antagonist to MSU crystals. Several amino acids in these two receptors are involved in the hydrophobic interactions with these phytochemicals but their interaction occurs in the binding site of the receptor rather than the active site. 
Table 6. Docking score values of compounds with TLR-2 and TLR-4.

\begin{tabular}{|c|c|c|c|}
\hline S.No & COMPOUND NAME & TLR-2 & TLR-4 \\
\hline 1 & $\begin{array}{l}\text { oxiraneoctanoic acid 3-octyl- methyl } \\
\text { ester }\end{array}$ & -163.55 & -4.23 \\
\hline 2 & 1-Terpinen-4-ol & -87.12 & -48.46 \\
\hline 3 & Flavone & -130.62 & -51.91 \\
\hline 4 & Tetradecanoic acid & -86.86 & -23.10 \\
\hline 5 & $\begin{array}{l}\text { 1-oxacyclopentadecan-2-one, } \\
15 \text {-isopropenyl }\end{array}$ & -158.58 & -6.31 \\
\hline 6 & $\begin{array}{l}\text { Pentadecanoic acid, 14-methyl,- } \\
\text { methyl ester }\end{array}$ & -131.38 & -17.74 \\
\hline 7 & Hexadecanoic acide, ethyl ester & -156.67 & -14.12 \\
\hline 8 & 10-Octadecenoic acid, methyl ester & -140.91 & -5.89 \\
\hline 9 & Oleic acid & -111.70 & -37.48 \\
\hline 10 & $\begin{array}{l}\text { Z,E-2-Methyl-3,13-octadecadien-1- } \\
\text { ol }\end{array}$ & -131.39 & -59.57 \\
\hline 11 & $\begin{array}{l}\text { 2-Oxo-5-benzoxy-6-methyl-4- } \\
\text { phenyl-1,2,3,4-tetrahydropyrimidine }\end{array}$ & -212.66 & -40.83 \\
\hline 12 & Isopropyl stearate & -145.05 & -78.57 \\
\hline 13 & $\begin{array}{l}\text { 4-one,2-(3,4-dihydroxyphenyl)-2,3- } \\
\text { dihydro-3,5,7-trihydroxy- }\end{array}$ & -97.48 & -7.44 \\
\hline 14 & Colchicines & -145.54 & -27.06 \\
\hline
\end{tabular}

\section{DISCUSSION}

In gout the uric acid in the form of monosodium urate crystals get deposited in the joints, synovial fluid and other tissues and causes an inflammatory and painful condition called as gouty arthritis (Albrecht et al., 2014). The inflammatory response in gout is characterized by multiple steps and complex interactions between various cell types which ultimately leads to the ulceration of the joint cartilage, marginal osteophytosis, and chronic inflammation of synovial membrane (Dalbeth and Haskard, 2005; Carado et al., 2006). The goals of gouty arthritis treatment are several fold. Initially, the drug should inhibit the overexpressed xanthine oxidase enzyme responsible for the production of uric acid. In the present investigation, the ethanolic extract of Cissus quadrangularis inhibited the xanthine oxidase enzyme considerably. The presence of high content of phytosterol, calcium, ascorbic acid $\beta$-sitosterol, $\delta$-amyrin, carotene and $\delta$-amyronehave the ability to modify the metabolic and physiological effects as reported by Metha et al. (2001); Shirwaikar et al. (2003). These may be responsible for the xanthine oxidase inhibitory activity observed in the present study.

The binding of the MSU ligand as an agonist to TLR2 and TLR4 receptors in the neutrophils is the initial trigger to the immune response and inflammatory stimuli which orchestrate the multiple signaling pathways such as activating the NLRP3 inflammasome, resulting in processing and secretion of IL-1 $\beta$, increased NF-kB activity, triggering the cytokines, such as interleukin-1 (IL-1), IL-6, IL-8, and tumor necrosis factor, matrix metalloproteinase (MMPs), and certain other mediators leading to the pathogenesis of gouty arthritis. (Haskard and Landis, 2002; Landis and Haskard, 2001). Similar to other forms of arthritis, there also the three basic interrelated processes like inflammation, synovial proliferation and joint tissue destruction that occurs in gouty arthritis. So the in vitro anti-arthritic activity in terms of inhibition of protein denaturation, membrane stabilization, and proteinase inhibition was studied for our plant extracts. The EECQ exhibited better anti gouty arthritic activity for membrane stabilization, inhibition of protease enzyme and protein denaturation. It is a wellknown fact that the lysosomal membrane is similar to the RBC membrane and any constituent which protects the RBC membrane has the ability to protect the lysosomal membrane. This, in turn, inhibits the release of protein-degrading enzymes from the neutrophils at the inflammatory site and thereby tissue inflammation and damage (Chou CT, 1997). All types of inflammatory processes usually trigger directly or indirectly the different types of immunological mediators which subsequently induce the proteases and destruction of cells and tissues. Phytochemicals which specifically inhibit these inflammatory mediators have the protective effect as an anti-gout agent. According to Panthonget al. (2007), the analgesic and anti-inflammatory activity of the plant extract is due to the presence of flavonoids especially luteolin and by $\beta$-sitosterol. Delapureta et al. (2005), have stated that the influx of neutrophils, as well as reduction of enzymes like MPO in the inflamed tissue, can be reduced by the $\beta$-sitosterol present in the Cissus quadrangularis extract.

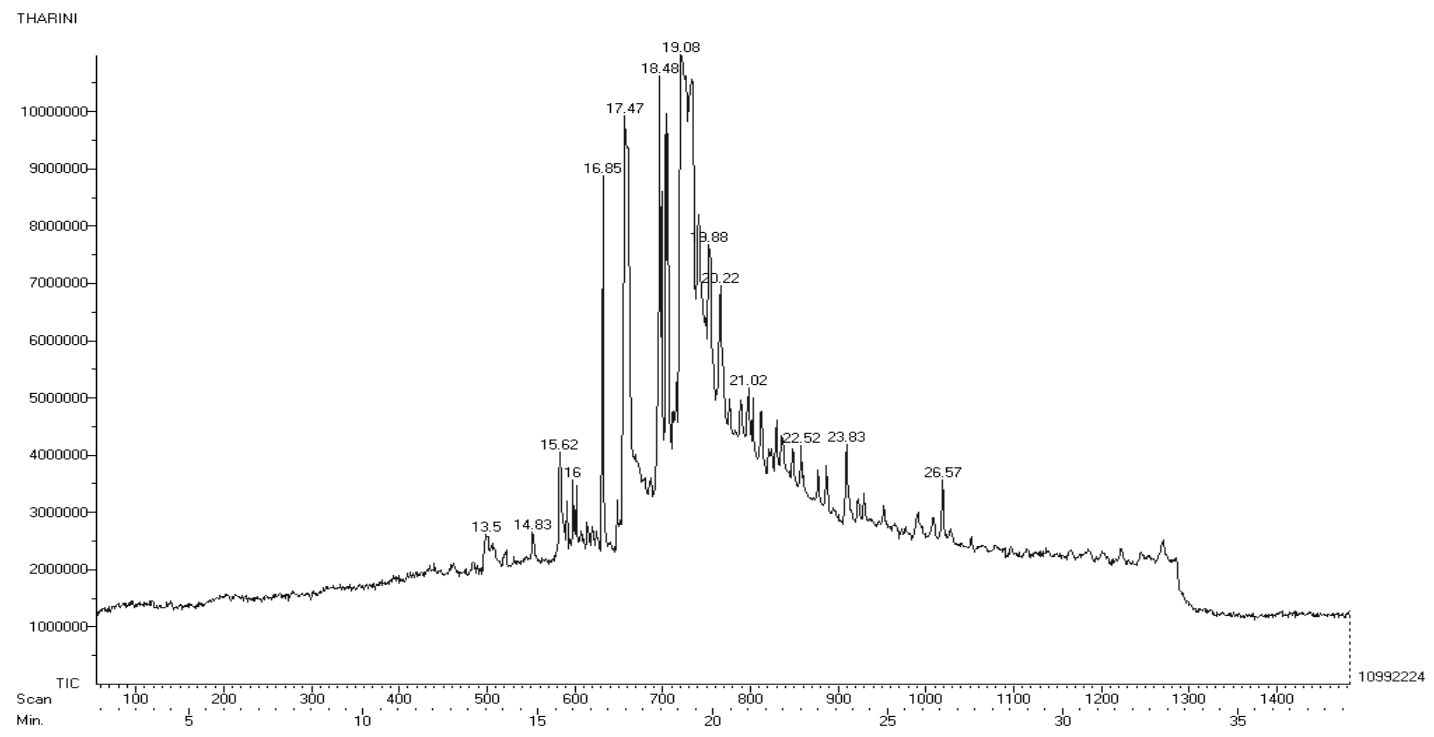

Fig. 1: Shows the list of bioactive compounds present in the EECQ with their retention time. 
Table 7: Interaction with the TLR-2 and TLR-4 proteins with phytochemicals of EECQ.

\begin{tabular}{|c|c|c|c|c|c|}
\hline \multirow{2}{*}{ S. No } & \multirow{2}{*}{ Compound } & \multicolumn{2}{|c|}{ TLR-2 amino acid binding site } & \multicolumn{2}{|r|}{ TLR-4 amino acid binding site } \\
\hline & & $\mathrm{H}$ bonding sites & Hydrophobic contact sites & $\mathrm{H}$ bonding sites & Hydrophobic contact sites \\
\hline & & 1 & 87 & 1 & 63 \\
\hline 1 & $\begin{array}{l}\text { Pentadecanoic } \\
\text { acid, 14-methyl,- } \\
\text { methyl ester }\end{array}$ & $\operatorname{Arg} 155(\mathrm{~A})$ & $\begin{array}{l}\text { Gln152(A), Leu176(A), Glu177(A), } \\
\text { Glu178(A), Glu180(A). }\end{array}$ & Arg289(B) & $\begin{array}{l}\text { Lys230(B), Arg234(B), Val259(B), Arg264(B), } \\
\text { Ala271(B), Val316(B), Ser317(B) }\end{array}$ \\
\hline \multirow[b]{2}{*}{2} & \multirow[b]{2}{*}{$\begin{array}{l}\text { 10-Octadecenoic } \\
\text { acid, methyl ester }\end{array}$} & 1 & 91 & & 47 \\
\hline & & $\operatorname{Arg} 155(\mathrm{~A})$ & $\begin{array}{l}\text { Gln152(A), Thr174(A), } \\
\text { Glu178(A), Glu180(A) }\end{array}$ & - & $\begin{array}{l}\text { Arg234(B), Arg264(B), Arg289(B), Ala291(B), Tyr296(B), } \\
\text { Ser317(B), Asn339(B), Lys341(B), Lys362(B) }\end{array}$ \\
\hline \multirow{2}{*}{3} & $\begin{array}{c}\text { 4-one,2-(3,4- } \\
\text { dihydroxyphenyl)- } \\
\text { 2,3-ihydro-3,5,7- } \\
\text { trihydroxy- }\end{array}$ & 3 & 75 & \multirow[t]{2}{*}{-} & 62 \\
\hline & \multirow{3}{*}{ Colchicines } & $\begin{array}{l}\text { Leu154(A), } \\
\text { Arg155(A), } \\
\text { Glu178(A). }\end{array}$ & $\begin{array}{l}\text { Val156(A), Asp160(A), } \\
\text { Glu180(A), Ile181(A). }\end{array}$ & & $\begin{array}{l}\text { Arg264(B), Leu293(B), Asp294(B), Tyr296(B), Thr319(B), } \\
\text { Asn339(B), Lys341(B), Lys362(B). }\end{array}$ \\
\hline \multirow[b]{2}{*}{4} & & 2 & 102 & 3 & 95 \\
\hline & & $\begin{array}{l}\text { Glu283(A), } \\
\text { Asp286(A). }\end{array}$ & $\begin{array}{l}\text { Phe256(A), Arg257(A), Asn258(A), } \\
\text { Ser265(A), Asp285(A) }\end{array}$ & $\begin{array}{l}\text { Asp294(B), } \\
\text { Tyr296(B), } \\
\text { Asn339(B). }\end{array}$ & Tyr292(B), Tyr295(B), Ser317(B). \\
\hline
\end{tabular}

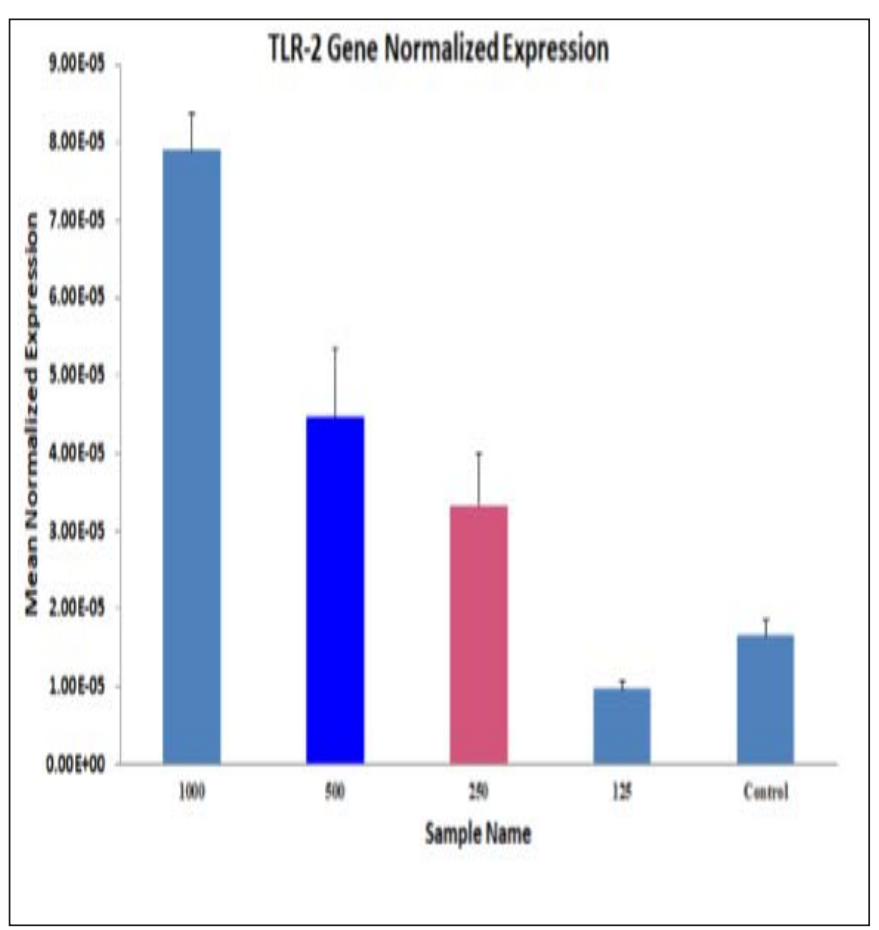

Fig. 2: TLR-2 gene expression chart.

In the present study, we could able to conclude that there is an association between the MSU crystals and overexpression TLR 2 and TLR4 genes. The expression pattern was high for theTLR4 gene than the TLR 2 gene. So we also made an attempt to examine whether the phytochemicals present in the Cissus quadrangularis stem extract could act as an antagonist to these transmembrane protein receptors (TLR 2 and TLR4) and thereby inhibit the down streaming inflammatory processes. Based on the GC-MS analysis of the ethanolic extract of the Cissus quadrangularis stem 14 compounds were subjected to patch dock method of molecular docking analysis. Three compounds namely Pentadecanoic acid,14methyl,-methyl ester, 10-Octadecenoic acid,methyl ester, 4-one,2(3,4-dihydroxyphenyl)-2,3-dihydro-3,5,7-trihydroxy showed better activation energy and docking score. These three compounds were further subjected for the ligand-protein interactions for the possible antagonist action for the TLR 2 and TLR 4 trans-membrane receptor. This blocking of the TLR 2 and TLR4 transmembrane receptor could hinder the further immunological reactions and protect the joints from destruction and pain.

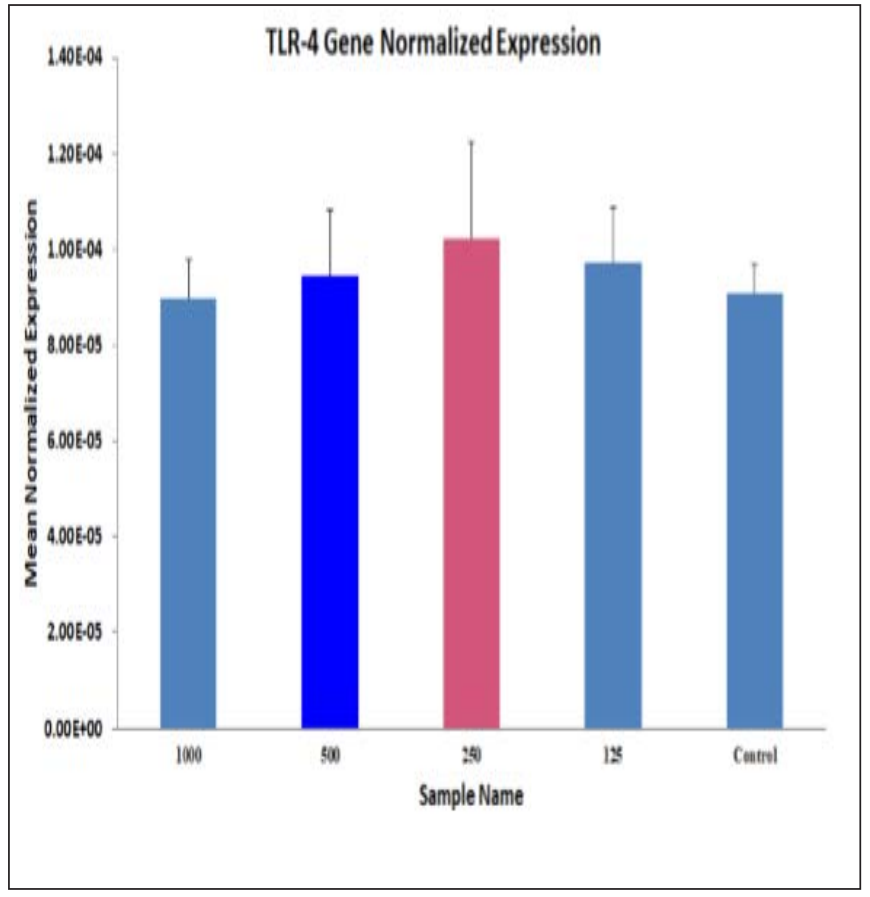

Fig. 3: TLR-4 gene expression chart. 


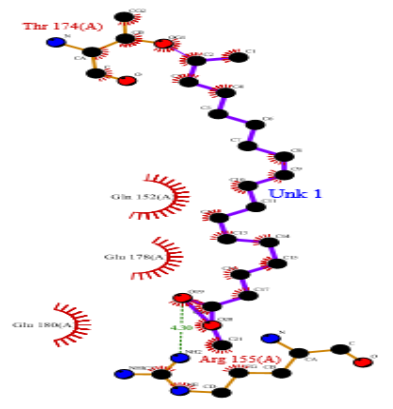

(A)

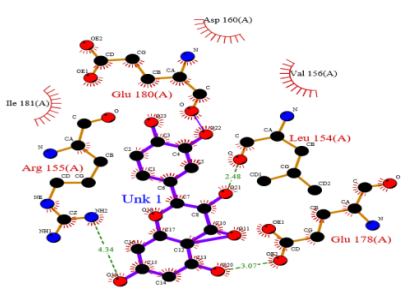

(C)

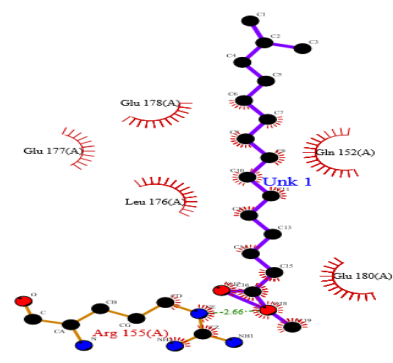

(B)

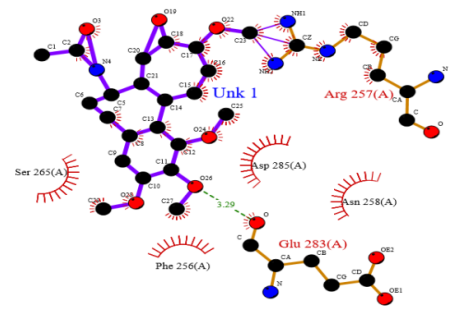

(D)

Fig. 4: Amino acid Interaction of TLR-2 protein with specific ligands. A) Pentadecanoic acid,14-methyl,-methyl ester. (B) 10-Octadecenoic acid, methyl ester. (C) 4-one,2-(3,4-dihydroxyphenyl)-2,3-dihydro-3,5,7-trihydroxy. (D) colchicines.

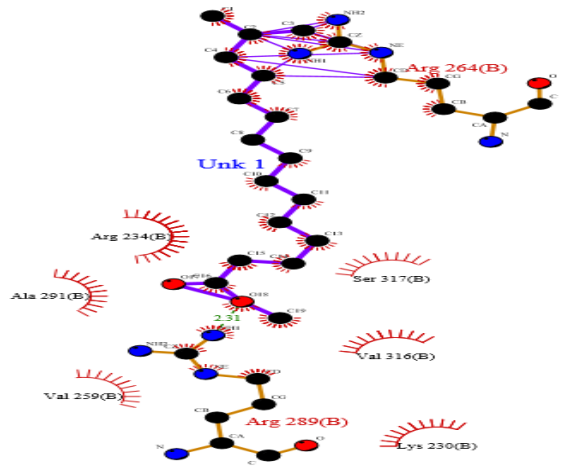

(A)

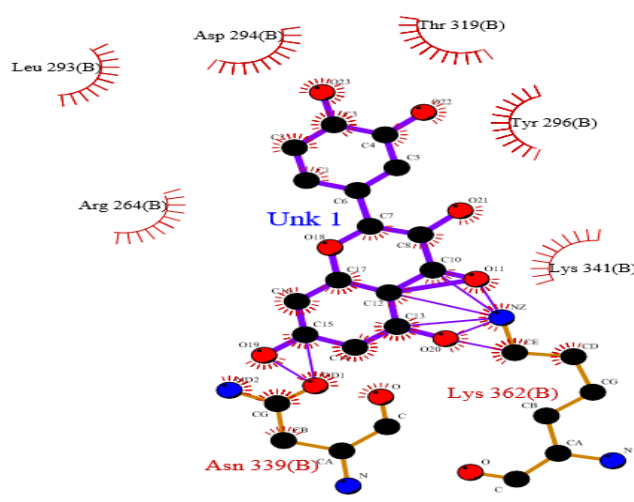

(C)

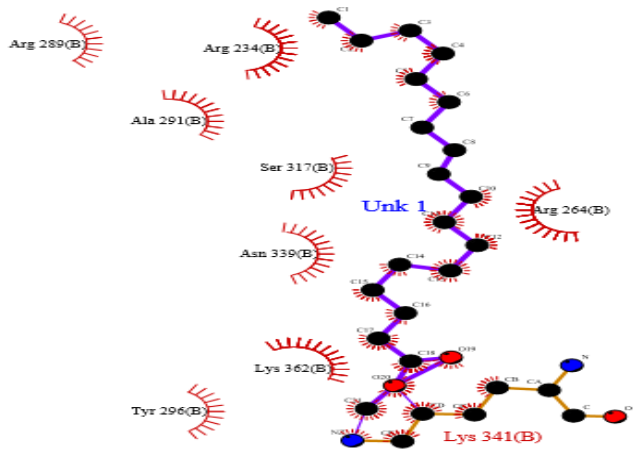

(B)

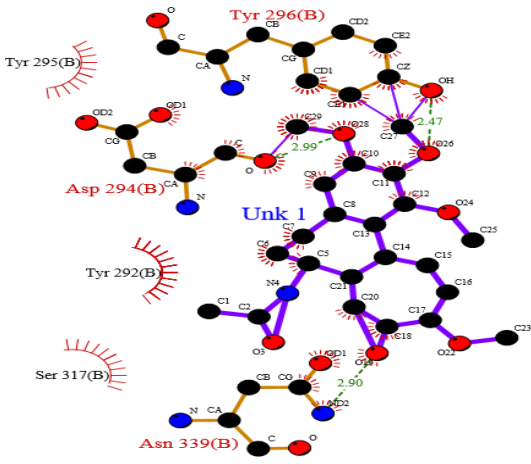

(D)

Fig. 5: Amino acid Interaction of TLR-4 protein with specific ligands. (A) Pentadecanoic acid,14-methyl,-methyl ester (B) 10-Octadecenoic acid, methyl ester. (C) 4-one,2-(3,4-dihydroxyphenyl)-2,3-dihydro-3,5,7-trihydroxy (D) colchicine. 


\section{CONCLUSION}

This knowledge will provide a new insight for the discovery of a single ligand which will be acting as an inhibitor for this TLR2 and TLR4 trans-membrane receptors thereby terminating the diverse immunochemical reactions leading to the pathogenesis of gouty arthritis. The single ligand may be used as a successful drug for the management of gouty arthritis which can replace the different types of drug which are at present in use for the treatment of gouty arthritis.

\section{REFERENCES}

Albrecht E, Waldenberger M, Krumsiek J, Evans AM, Jeratsch $\mathrm{U}$, Breier $\mathrm{M}$, et al. Metabolite profiling reveals new insights into the regulation of serum urate in humans. Metabolomics, 2014; 10:141-151.

Chou CT. The anti-inflammatory effect of Tripterygium wilfordii Hook $\mathrm{F}$ on adjuvant induced paw edema in rats and inflammatory mediators release. Phytother Res, 1997; 11(2):152-54.

Corrado A, Onofrio FD, Santoro N, Melillo N, Cantatore FP. Pathogenesis, clinical findings and management of acute and chronic gout. Minerva Med, 2006; 97:495-509.

Dalbeth N, Haskard DO. Mechanism of inflammation in gout. Rheumatology, 2005; 44:1090-1096.

Delapureta R, Martinez DE, Ruiz GV. Effect of minor components of virgin olive oil on topical anti-inflammatory assays. Zetschrift Fur Naturforschong, 2000; 55:814-19.

Getting SJ, Christian HC, Flower RJ, Perretti M. Activation of melanocortin type 3 receptor as a molecular mechanism for adrenocorticotropic hormone efficacy in gouty arthritis. Arthritis Rheum, 2002; 46:2765-2775.

Haskard DO, Landis RC. Interactions between leukocytes and endothelial cells in gout: lessons from a self-limiting inflammatory response. Arthritis Res., 2002; 3:91.

Landis RC, Haskard DO. Pathogenesis of crystal-induced inflammation.Curr. Rheumatol. Rep, 2001; 3:36.

Liu-Bryan R, Pritzker K, Firestein GS, Terkeltaub R. TLR2 signaling in chondrocytes drives calcium pyrophosphate dehydrate and monosodium urate crystal-induced nitric oxide generation. J Immunol, 2005; 174:5016-5023.

Liu-Bryan R, Scott P, Sydlaske A, Rose DM, Terkeltaub R. Innate immunity conferred by toll-like receptors 2 and 4 and myeloid differentiation factor 88 expression is pivotal to monosodium urate monohydrate crystalinduced inflammation. Arthritis Rheum, 2005; 52:2936-2946.
Mehta M, Kaur N, Bhutani KK. Determination of marker constituents from Cissus quadrangularisLinn. and their quantitation by HPTLC and HPLC. Phytochem Anal, 2001; 12:91-5.

Mishra G, Srivastava S, Nagori BP. "Pharmacological and therapeutic activity of Cissus quadrangularis: An overview" International Journal of Pharm. Tech. Research, 2010; 2(2):1298-1310.

Mizushima Y, Kobayashi M. "Interaction of anti-inflammatory drugs with serum proteins especially with some biologically active proteins" J Pharm Pharmacol, 1968; 20:169-73.

Owen P, Johns T. Xanthine oxidase inhibitory activity of north eastern North American plant remedies used for gout, J Ethnopharmacol, 1999; 64:149.

Oyedapo, Famurewa AJ. "Anti-protease and membrane stabilizing activities of extracts of Fagra zanthoxiloides, Olax subscorpioides and Tetrapleura tetraptera". Int J. pharmacogn, 1995; 33:65-9.

Panthong A, Wanicha S, Kanjanapothi D, Tawat T, Vichai R. Analgesic, anti-inflammatory and venotonic effects of Cissus quadrangularis Linn. Journal of Ethnophramacology, 2007; 110:264-70.

Sakat S, Juvekar AR, Gambhire MN. Inv itro antioxidant and anti-inflammatory activity of methanol extract of Oxalis corniculata Linn. Inter. J. Pharma Parmacol Sci, 2010; 2(1):146-55.

Seegmiller JE, Howel RR, Malaw ISTASE. The inflammatory reaction to urate. JAMA, 1962; 180:469-75.

Shirwaikar A, Khan S, Malini S. Antiosteoporotic effect of ethanol extract of Cissus quadrangularis Linn. on ovariectomized rat. J Ethnopharmacol, 2003; 89:245-50.

Slinkard J, Singleton VL. Total phenol analysis: automation and comparison with manual methods. Am J Enol Vitic, 1977; 28:49.

Unno T, Sugimoto A, Kakuda T. Xanthine oxidase inhibitors from the leaves of Lagerstroemia speciosa (L.) Pers. J. Ethnopharmacol, 2004; 93:391-395.

Yoganarsimhan SN. Medicinal plants of India. Cyber Media Bangalore 2, 2000; 2:136-137.

Zhishen J, Mengcheng T, Jianming W. The determination of flavonoid contents in mulberry and their scavenging effects on superoxide radicals. Food Chem, 1999; 64:555.

How to cite this article:

Palani T, Shobha K, Thirunavukkarasu P, Hari R. In vitro and In silico Antigout arthritic activities of Ethanolic and Aqueous stem extracts of Cissus quadrangularis - A TLR2 and TLR4 Receptor approach. J App Pharm Sci, 2018; 8(09): 015-022. 